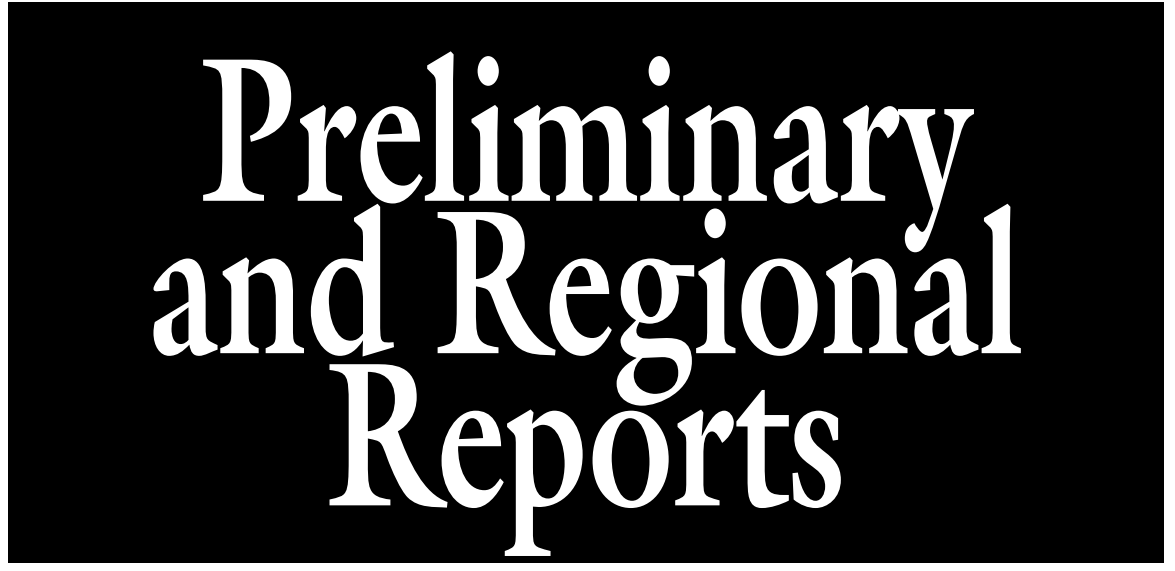

\section{Organic Mulch Effects on High Tunnel Lettuce in Southern New England}

\author{
Rahmatallah Gheshm ${ }^{1}$ and Rebecca Nelson Brown ${ }^{2}$
}

ADDITIONAL INDEX WORDS. multisource compost, soil temperature, season extension, romaine, Lactuca sativa

SUMmARY. Lettuce (Lactuca sativa L.) is a popular crop for spring and fall high tunnels among direct-market vegetable producers. Common practices include the use of compost as a soil amendment, and reliance on cultivation for weed control. This study examined the impacts of using compost as a surface mulch to control weeds in spring and fall romaine lettuce, with data collected on soil temperature, weed suppression, and lettuce yields. Costs of all inputs, including labor, were tracked to assess economic feasibility of using mulch. Compost mulch was compared with bare ground with cultivation across four cultivars of romaine lettuce: Ridgeline, Coastal Star, Green Forest, and Shushan. In the fall experiment, mulching increased average soil temperature by $1^{\circ} \mathrm{C}$ and canopy cover, leaf area index (LAI), and fresh and dry weights were significantly higher in mulched plots. Mulching decreased daily variation in soil temperature in the spring experiment but had no effect on average soil temperature. Canopy cover, LAI, and fresh and dry weights were not significantly affected by mulching in the spring experiment. Compost mulch affected all cultivars similarly in both experiments, with no significant interaction effects. Yields were greater and leaves were larger in the spring experiment than in the fall for all cultivars. Fresh weight yields in the spring experiment averaged $3.22 \mathrm{~kg} \cdot \mathrm{m}^{-2}$ and heads had a LAI of 7.9 as compared with $1.02 \mathrm{~kg} \cdot \mathrm{m}^{-2}$ and 1.6 for the fall experiment. Dry matter content (DMC) was significantly higher in the fall lettuce $\left(113 \mathrm{~g} \cdot \mathrm{kg}^{-1}\right)$ than in the spring lettuce $\left(43 \mathrm{~g} \cdot \mathrm{kg}^{-1}\right)$. Cultivar rank order was consistent across experiments, with 'Ridgeline' having the best performance and 'Green Forest' the worst. 'Coastal Star' and 'Shoshone' were intermediate and very similar to each other. Although the use of compost as a mulch increased yields of all cultivars in the fall experiment, only the top cultivar, Ridgeline, produced enough additional yield to offset the increased costs of the compost mulch used in this study. The use of a less-expensive compost or a higher retail price for romaine lettuce would have made the economics more favorable for the other cultivars.

L ettuce is one of the most important fresh market vegetable crops in the United States. In 2017 , lettuce was grown on more than 276,000 acres, with a crop value exceeding $\$ 3.6$ billion [U.S. Department of Agriculture (USDA), 2018]. Most of the U.S. lettuce crop is grown in California and Arizona, but according to the 2012 Census of Agriculture, lettuce was planted on loss of freshness of products because of transit time, and consumer demand for fresh, healthy, and local produce. Along with butterhead lettuce, romaine and leaf lettuce have been grown commercially in the eastern United States for more than 100 years, whereas crisphead lettuce is shipped from the western United States (Ryder, 2002). Many directmarket growers use high tunnels to extend their production season and increase farm income (Bruce et al., 2017; Martinez et al., 2010). Lettuce is the number two crop grown in high tunnels in the United States (Orzolek, 2012). In Rhode Island, lettuce can be harvested from outdoor plantings from May until October; high tunnels allow the harvest season to be extended to include March, November, and December.

Multiple studies have reported success in growing romaine or leaf lettuce in high tunnels, with quality and marketable yields exceeding those of lettuce grown in the open field, particularly in early spring and late fall when weather is unstable (Rader and Karlsson, 2006; Wallace et al., 2012). The rain exclusion benefits of high tunnels in combination with drip irrigation reduce germination of weed seeds relative to the open field (Lamont et al., 2003), but weed control is still necessary in tunnels, particularly during periods of high soil moisture. Plastic mulches are an established practice for weed control in high tunnels, particularly for tomato (Solanum lycopersicum L.) and other heat-loving vegetables (Lamont et al., 2003). However, many growers prefer not to use plastic mulches in high tunnels. The cost of equipment for laying and removing plastic is a barrier to adoption (Goldberger et al., 2015), as are the need to till the soil before laying plastic mulch, and the environmental issues surrounding manufacture and disposal of plastic films (Goldberger et al., 2015). Although paper, straw matting and biodegradable plastic films have been successfully used as alternatives to plastic in high tunnels, equipment and tillage requirements are similar to plastic (Cowan et al., 2014; Sánchez et al., 2008; Wortman et al., 2016).

Many growers apply organic soil amendments, including composts, annually in high tunnels to build soil fertility (Knewtson et al., 2010). 
Lettuce responds well to organic nutrient sources, and compost amendments have been shown to increase yields and quality of romaine lettuce relative to inorganic fertilizers (Hernández et al., 2016). The use of organic mulches, particularly composts, may be an appropriate weedcontrol strategy in high tunnels for growers who do not wish to use plastic mulch. High tunnels have been shown to slow decomposition of particulate organic matter relative to the open field (Knewtson et al., 2012) and organic matter levels can become quite high after years of routine addition of composts. However, soil organic matter can become depleted when tunnels are conventionally managed with synthetic fertilizers and frequent tillage (Bonanomi et al., 2014; Knewtson et al., 2012). Incorporation of organic mulches has been shown to improve soil health in high tunnel production systems, where many years of intensive vegetable production had depleted soil organic carbon (Bonanomi et al., 2014).

Organic mulches are known to reduce soil temperatures when used during the summer (Munn, 1992; Sánchez et al., 2008). Soil warming has been shown to increase yields of lettuce grown in high tunnels in early spring and late fall (Bumgarner et al., 2011), and soil-cooling effects of organic mulches could be detrimental when high tunnels are used for season extension. Previous studies of early spring romaine and leaf lettuce production in high tunnels have used black plastic mulch to increase soil temperatures (Wallace et al., 2012). The objective of this study was to determine how using compost as an organic mulch for weed suppression affected yields of romaine lettuce cultivars grown in the late fall and early spring when below-optimal soil temperatures could limit lettuce growth. We chose to test four cultivars of lettuce because cultivars are known to differ in tolerance of environmental conditions expected in high tunnels

\footnotetext{
Department of Plant Sciences and Entomology, University of Rhode Island, Kingston, RI 02881

We thank Timothy Sherman for help with field work. ${ }^{1}$ Visiting Scientist from Department of Agronomy, Ferdowsi University of Mashhad, Iran.

${ }^{2}$ Corresponding author. E-mail: brownreb@uri.edu.

https://doi.org/10.21273/HORTTECH04056-18
}

in Rhode Island in fall and spring, and might differ in response to compost mulch. We chose to use compost because it is an accepted amendment for use in high tunnels, avoiding concerns that raw organic materials could reduce soil nutrient availability or introduce contaminants. Organic mulch was not compared with plastic or paper mulch because farmers in Rhode Island generally do not use plastic or paper mulch in high tunnels, although silage tarps and woven landscape weed barrier are used for weed suppression with tomatoes. In addition to the costs for labor or equipment for laying mulch, plastic mulch has been shown to increase damage from meadow vole (Microtus pennsylvanicus Ord.), a major pest of high tunnel greens production in Rhode Island (Eaton, 2017).

\section{Materials and methods}

The study was conducted at the University of Rhode Island's Gardner Crops Research Center in Kingston from Sept. 2016 to May 2017. The high tunnel used in the study was constructed in 2011; it measures $21 \mathrm{ft}$ wide, $72 \mathrm{ft}$ long, and $13 \mathrm{ft}$ high. The tunnel is covered by two layers of greenhouse plastic with inflation and is equipped with manual roll-up sides and an automated roll-up roof vent running the length of the tunnel. Soil inside the tunnel is Bridgehampton silt loam, which has been amended repeatedly over time with compost and organic fertilizers. The soil has a pH of $7.0,5.2 \%$ organic matter, and high levels of calcium, magnesium, phosphorus, and potassium. Average daily temperatures during the study ranged from $25.5^{\circ} \mathrm{C}$ in September to $-5.1{ }^{\circ} \mathrm{C}$ in December, and from $-2.9{ }^{\circ} \mathrm{C}$ in March to $20.5{ }^{\circ} \mathrm{C}$ in May. Inside the high tunnel, daytime temperatures ranged from minimum $0{ }^{\circ} \mathrm{C}$ to maximum $31{ }^{\circ} \mathrm{C}$ and overnight lows from minimum $-5{ }^{\circ} \mathrm{C}$ to maximum $18.5{ }^{\circ} \mathrm{C}$. Average solar radiation outside the tunnel was 9.93 and $17.46 \mathrm{MJ} \cdot \mathrm{m}^{-2} \cdot \mathrm{d}^{-1}$ in fall and spring experiments, respectively.

Four full-size romaine lettuce cultivars were used for this study: Ridgeline, Coastal Star, Green Forest, and Shushan. 'Ridgeline' is best suited to spring and fall production. 'Coastal Star' was developed for organic production systems; it is dark green and heat tolerant. 'Green Forest' is an early cultivar with tall heads developed for shipping. Seeds of these cultivars were obtained from Johnny's Selected Seeds (Albion, ME). 'Shushan' is adapted to arid climates; seeds were obtained from Falat Iran Co. (Tehran, Iran). Lettuce was seeded on two dates, 1 Sept. 2016 and 19 Feb. 2017, into plug trays with a cell volume of $22 \mathrm{~cm}^{3}$ (102 HEX plug trays; Landmark Plastics, Akron, $\mathrm{OH}$ ) filled with a bark and peatmoss-based greenhouse medium with starter nutrients (Metromix 510; Sun Gro Horticulture, Agwam, MA). Fall transplants were grown for $35 \mathrm{~d}$ outdoors under ambient conditions, followed by $10 \mathrm{~d}$ in the high tunnel before transplanting into the experimental plots on 14 Oct. Spring transplants were grown for $3 \mathrm{l} \mathrm{d}$ in the greenhouse under natural light and were transplanted into the experimental plots on 20 Mar.

Fall and spring trials were treated as separate split plot experiments with four replications. Each main plot consisted of three rows of each cultivar, with 16 plants/row. Rows were spaced $40 \mathrm{~cm}$ apart and plants were spaced $30 \mathrm{~cm}$ apart within the rows. Water was provided using drip tapes laid on the soil surface, beneath the

\begin{tabular}{llll}
\hline $\begin{array}{l}\text { Units } \\
\text { To convert U.S. to SI, } \\
\text { multiply by }\end{array}$ & U.S. unit & SI unit & $\begin{array}{l}\text { To convert SI to U.S., } \\
\text { multiply by }\end{array}$ \\
\hline 0.4047 & $\mathrm{acre}(\mathrm{s})$ & $\mathrm{ha}$ & 2.4711 \\
0.3048 & $\mathrm{ft}$ & $\mathrm{m}$ & 3.2808 \\
0.0929 & $\mathrm{ft}^{2}$ & $\mathrm{~m}^{2}$ & 10.7639 \\
3.7854 & gal & $\mathrm{L}$ & 0.2642 \\
2.54 & inch $(\mathrm{es})$ & $\mathrm{cm}$ & 0.3937 \\
6.4516 & inch & & \\
0.0418 & langley(s) & $\mathrm{cm}^{2}$ & 0.1550 \\
0.4536 & $\mathrm{MJ} \cdot \mathrm{m}^{-2}$ & 23.9006 \\
1.1209 & $\mathrm{lb}$ & $\mathrm{kg}$ & 2.2046 \\
4.8824 & $\mathrm{lb} / \mathrm{acre}$ & $\mathrm{kg} \cdot \mathrm{ha}^{-1}$ & 0.8922 \\
62.5000 & $\mathrm{lb} / \mathrm{ft}^{2}$ & $\mathrm{~kg} \cdot \mathrm{m}^{-2}$ & 0.2048 \\
$\left({ }^{\circ} \mathrm{F}-32\right) \div 1.8$ & $\mathrm{Oz} / \mathrm{lb}$ & $\mathrm{g} \cdot \mathrm{kg}^{-1}$ & 0.0160 \\
& ${ }^{\circ} \mathrm{F}$ & ${ }^{\circ} \mathrm{C}$ & $\left({ }^{\circ} \mathrm{C} \times 1.8\right)+32$
\end{tabular}


mulch. Two lines of drip tape were used in each plot; emitters were spaced 12 inches apart and had a flow rate of $0.45 \mathrm{gal} / \mathrm{min}$ (Jain Irrigation, Watertown, NY). Plots were irrigated immediately after transplanting and then every 2 weeks until harvest.

Each main plot was split into two subplots, each $2.7 \mathrm{~m}^{2}$ in area. One subplot was mulched with a $5-\mathrm{cm}$ layer of compost (Earth Care Farm, Charlestown, RI); the other contained bare soil. The compost was made from farm animal manure, leaves, woodchips, fish scraps, shellfish waste, seaweed, spent mushroomgrowing medium, food scraps, coffee grounds, and wood ash in outdoor turned windrows. Nutrient content of oven-dried compost was estimated at $1.3 \%$ nitrogen, $0.25 \%$ phosphorus, and $1.2 \%$ potassium. As applied, the compost was $\approx 40 \%$ water, reducing actual nutrient content. At the conclusion of the fall experiment, the mulch was raked uniformly across the high tunnel and soil incorporated; new mulch was applied for the spring experiment.

Air and soil temperatures were recorded at 4-h intervals using temperature sensors with integrated data loggers (Thermochron iButton; Maxim Integrated, San Jose, CA). Soil temperature loggers were placed at $5 \mathrm{~cm}$ depth between plants in the center of each subplot. Air temperature loggers were installed at $25 \mathrm{~cm}$ height above the ground. Plants were fertigated through the drip tape with water-soluble fertilizer (Aquatrols, Paulsboro, NJ) to provide $38 \mathrm{~kg} \cdot \mathrm{ha}^{-1}$ nitrogen $(\mathrm{N}), 13.6 \mathrm{~kg} \cdot \mathrm{ha}^{-1}$ phosphorus $(\mathrm{P})$, and $28.2 \mathrm{~kg} \cdot \mathrm{ha}^{-1}$ potassium (K). No preplant fertilizer was applied, as soil nitrogen levels were high because of continued release from organic fertilizers used with the Summer 2016 tomato crop, and soil tests indicated all other nutrients were at or above optimum. Lettuce is much less responsive to nitrogen fertilization when temperatures and light levels are low (Van Der Boon et al., 1990). In the fall experiment, all nutrients were applied in a single fertigation event on 1 Nov. In the spring experiment, the application was split between two fertigation events on 15 and 29 Apr. Additional nutrients were provided by foliar spray on 15 Nov. and 1 Dec.; foliar sprays were not used in the spring experiment. Foliar sprays used liquid fertilizers
(FloraGro and FloraMicro; General Hydroponics, Santa Rosa, CA) diluted in water to provide $1.5 \mathrm{~kg} \cdot \mathrm{ha}^{-1} \mathrm{~N}$, $0.26 \mathrm{~kg} \cdot \mathrm{ha}^{-1} \mathrm{P}, 2.2 \mathrm{~kg} \cdot \mathrm{ha}^{-1} \mathrm{~K}$, and complete micronutrients.

All plots were monitored daily; no pest management was needed. Bare soil subplots were weeded by hand on 21 Oct. and 8 Nov. for the fall experiment, and on 1,14 , and 25 Apr. for the spring experiment. Data were not collected on weed biomass, but labor required for weeding was tracked. The mulched plots were not weeded. From 28 Nov. until harvest, plants in the fall experiment were covered at night by low tunnels of spunbonded fabric (Agribon-19; Berry Plastics, Evansville, IN) supported on wire hoops for protection against low temperatures. This is a standard practice in New England (Lamont, 2009).

Data were collected on canopy size, yield, biomass production, and LAI. Canopy size was estimated using a variation of the method of Bumgarner at al. (2012). Digital images were taken every 4-8 d from transplant to harvest. A white quadrat $(35 \times 35 \mathrm{~cm})$ was placed around the center two plants in each subplot and photographed from a height of $60 \mathrm{~cm}$ above the soil surface directly above the quadrat. Percent green cover within the quadrat was calculated using Canopeo (Patrignani and Ochsner, 2015) and converted to area units based on the known area of the quadrat. Lettuce was harvested on 13 Dec. and 18 May; average fresh weights were calculated from the total yield for each subplot. Two randomly selected heads per subplot were used to measure the total leaf area and shoot dry weight. Leaf area was measured by disassembling each head and spreading the leaves in a single layer in a $1-\mathrm{m}^{2}$ quadrat, photographing the quadrat, and measuring percent green pixels using Canopeo. LAI was calculated using the measured leaf area as the numerator and the area of the plot occupied by the plant as the denominator. Leaves were dried in a $43{ }^{\circ} \mathrm{C}$ oven until the weights were constant.

To determine the economic feasibility of using compost as mulch, we collected data on all inputs and labor practices which differed between treatments. Returns were estimated using the local retail price of romaine lettuce; this is appropriate because most lettuce grown in New England is sold directly to retail.

Data analysis was performed using the analysis of variance (ANOVA) and Duncan's multiple range test in SAS (version 9.2; SAS Institute, Cary, NC). Growth rate data were analyzed using repeated measures ANOVA. All the graphs were drawn by Excel (Microsoft, Redmond, WA).

\section{Results and discussion}

EFFECTS OF COMPOST MULCH ON SOIL AND WEEDS. In the fall experiment (Fig. 1), root zone soil temperatures were significantly $(P<0.0001)$ different between subplots, with a mean soil temperature of $13.5^{\circ} \mathrm{C}$ in mulched plots and $12.5^{\circ} \mathrm{C}$ in bare ground plots. Mulch did not affect mean soil temperature in the spring experiment; mean soil temperatures were $13.6{ }^{\circ} \mathrm{C}$ in mulched plots and

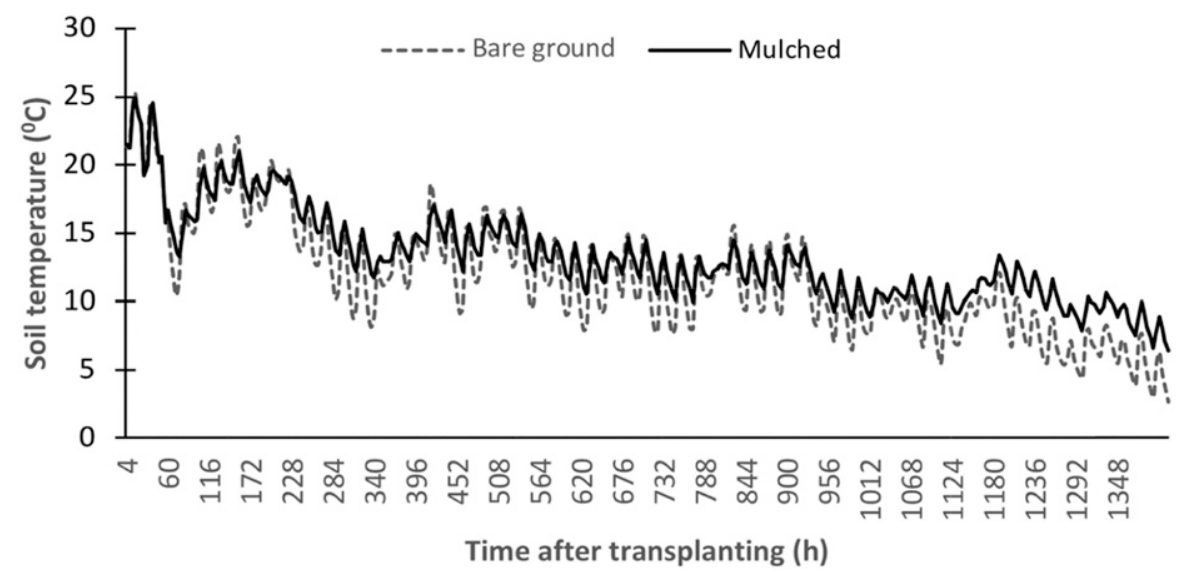

Fig. 1. Soil temperature in high tunnel lettuce plots mulched with compost or left bare during Fall 2016. Temperature was measured at $5 \mathrm{~cm}$ ( 2.0 inches $)$ depth every $4 \mathrm{~h}$ from 14 Oct. to $13 \mathrm{Dec}$.; lines represent the averages of 16 plots per treatment. Mean temperatures differed significantly between treatments; variance was homogeneous; $\left(1.8 \times{ }^{\circ} \mathrm{C}\right)+32={ }^{\circ} \mathrm{F}$. 
$13.9^{\circ} \mathrm{C}$ in bare ground plots. However, mulch significantly $(P<0.0001)$ reduced variability of the soil temperature (Fig. 2): soil in the bare ground treatment was warmer during the day and cooler at night than the soil in the mulch treatment. Other researchers have reported that organic mulch stabilizes root zone temperatures, slowing cooling in the fall and warming in the summer (Kosterna, 2014). Deguchi et al. (2009) reported that organic mulch increases soil temperature in cool climates by decreasing evaporation from the soil surface. Given the stabilizing effect of mulch on soil temperatures, we hypothesized that the mulched soil would be significantly cooler than the bare soil in the spring experiment, but the data do not support this hypothesis. The compost mulch was effective in suppressing weeds in both experiments; no weeds emerged in the mulched subplots, whereas the bare ground subplots required hand weeding twice during the fall experiment and three times during the spring experiment.

EFFECTS OF COMPOST MULCH ON CANOPY SIZE. In the fall experiment, differences in canopy cover between treatments became apparently concurrent with the arrival of cold weather (Fig. 3). Mean canopy size in the mulched treatment increased by $20.4 \mathrm{~cm}^{2}$ per plant each day from 5 Nov. until harvest, whereas mean canopy size in the bare ground treatment increased by only $18.2 \mathrm{~cm}^{2}$ per plant. In the spring experiment, plants in the bare soil treatment tended to be larger than plants in the mulched treatment on all dates, but the differences were statistically significant only on 8 and 15 Apr. and there were no significant differences in the growth rate curves as compared using repeated measures (Fig. 4). Mean canopy cover in the spring experiment increased by $30.1 \mathrm{~cm}^{2}$ per plant per day.

EFFECTS OF COMPOST MULCH ON LETTUCE YIELDS AND LEAF AREA. In the fall experiment, compost mulch significantly increased lettuce fresh weight and leaf area but did not affect DMC (Table 1). Heads from mulched plots had, on average, $20 \%$ more leaf area and were $21.7 \%$ heavier. Mulch treatment had no effect on lettuce weight or leaf area in the spring experiment (Table 1). These results suggest that the yield differences in the fall experiment were due to the mulched subplots maintaining a higher soil temperature. Nair and Havlovic (2012)

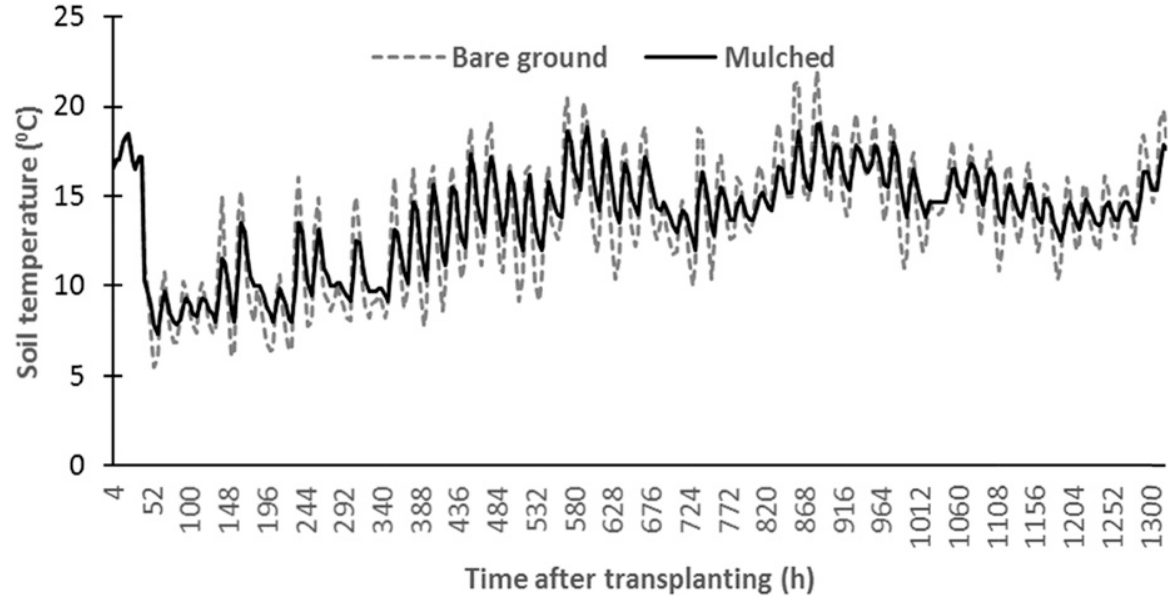

Fig. 2. Soil temperature in high tunnel lettuce plots mulched with compost or left bare during Spring 2017. Temperature was measured at $5 \mathrm{~cm}(2.0$ inches $)$ depth every $4 \mathrm{~h}$ from 20 Mar. to 18 May; lines represent the averages of four plots per treatment. Variation around the mean differed significantly between treatments but means did not differ; $\left(1.8 \times{ }^{\circ} \mathrm{C}\right)+32={ }^{\circ} \mathrm{F}$.

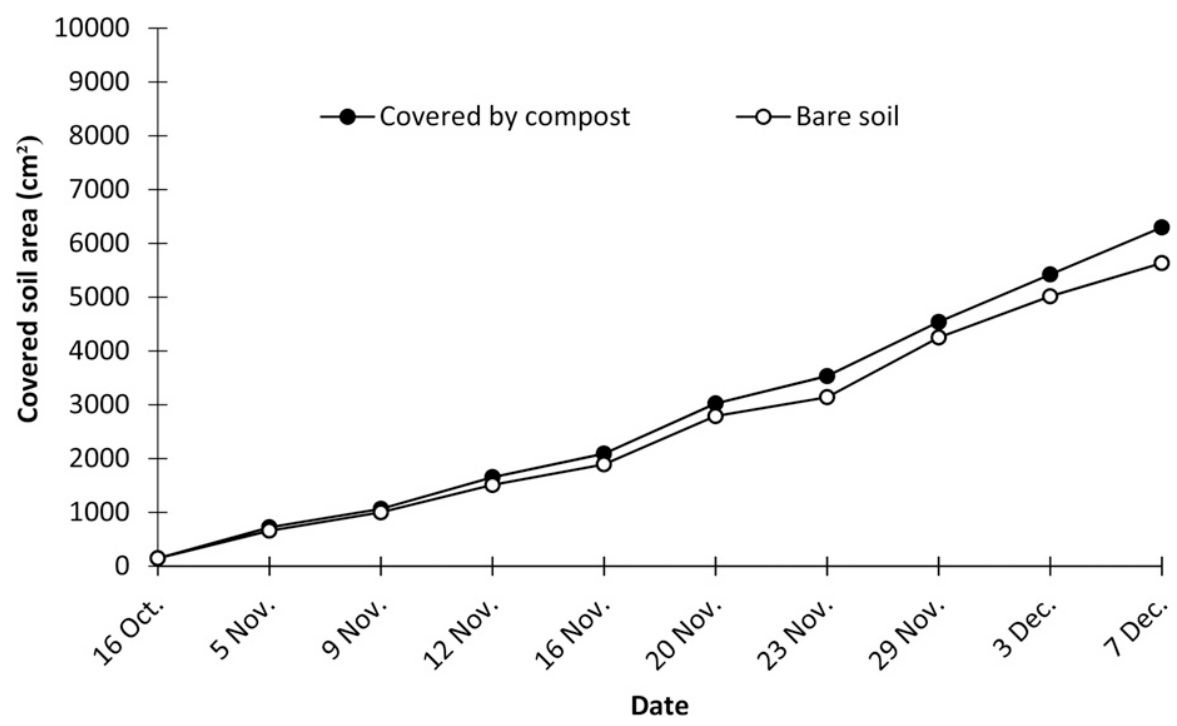

Fig. 3. Change in canopy size, measured as covered soil area, over time for romaine lettuce in soil mulched with compost or left bare. Lettuce was grown in the high tunnel in Fall 2016; data are averages across 16 replications. Means of treatment least squares differ significantly at $P<0.05 ; 1 \mathrm{~cm}^{2}=0.1550 \mathrm{inch}^{2}$.

reported that using black plastic mulch or lightweight spunbonded rowcovers in a fall crop of high tunnel lettuce increased soil temperatures and lettuce yields. Other researchers have increased lettuce yields in late fall and early spring by using electric soil heating cables to raise root zone temperatures (Bumgarner et al., 2011; Hunter, 2010). The lettuce growth rate is highly correlated to both accumulated growing degree days (GDD) at the soil surface and accumulated photosynthetically active radiation $(P A R)$, and once heading has been initiated, the growth response is exponential (Salomez and Hofman, 2007). In the fall experiment, solar radiation levels dropped below $10 \mathrm{MJ} \cdot \mathrm{m}^{-2} \cdot \mathrm{d}^{-1} 4$ weeks after the lettuce was transplanted, so for much of the head formation and filling stage, accumulation of GDD at the soil surface was the primary driver of growth. By contrast, solar radiation was 10.43 $\mathrm{MJ} \cdot \mathrm{m}^{-2} \cdot \mathrm{d}^{-1}$ when the lettuce in the spring experiment was transplanted into the high tunnel, and solar radiation increased throughout the experiment. Thus, both GDD and $P A R$ were driving lettuce growth during the spring experiment.

Cultivar effects. Compost mulch affected all cultivars similarly, with no significant interaction effects. 
Yields were higher and leaves were larger in the spring experiment for all cultivars. Yields in the spring experiment averaged $3.22 \mathrm{~kg} \cdot \mathrm{m}^{-2}$ and heads had a LAI of 7.9 as compared with $1.02 \mathrm{~kg} \cdot \mathrm{m}^{-2}$ and 1.6 for the fall $\mathrm{ex}^{-}$ periment. Lettuce cultivars vary in genetic yield, and also in relative growth rates. Growth is slowed under the cooler temperatures and lower light levels of late fall, so differences in growth rate can have substantial effects on yield. In the spring, differences in bolting tendency can affect yield. Significant differences in growth rate, LAI, and fresh and dry weights were found between cultivars in both experiments, and cultivar rank order was consistent across experiments. In the fall, size differences among cultivars became apparent by 5 Nov. and growth rates differed significantly $(P<0.01)$ until harvest (Fig. 5). In the fall experiment, 'Ridgeline' grew the most rapidly, with average plant size increasing by $23.4 \mathrm{~cm}^{2}$ per day, whereas 'Green Forest' plants grew the most slowly, increasing by $13.4 \mathrm{~cm}^{2}$ per day. In the spring, differences in size between cultivars were apparent at transplanting and growth rates differed significantly through harvest (Fig. 6). 'Ridgeline' had the largest canopy at harvest, covering $90 \%$ of the plot, whereas the 'Green Forest' canopy covered only $70 \%$. The rank order of cultivars in fall and spring was the same. 'Ridgeline' had the greatest LAI, averaging 1.98 in the fall (Table 2) and 9.09 in the spring (Table 2). 'Ridgeline' also had the largest heads, with a fresh weight of $1.26 \mathrm{~kg} \cdot \mathrm{m}^{-2}$ in the fall and $3.69 \mathrm{~kg} \cdot \mathrm{m}^{-2}$ in the spring. 'Green Forest' had the smallest leaf area and the lightest heads. 'Coastal Star' and 'Shoshan' were intermediate in LAI and yield, being significantly larger than 'Green Forest' but smaller than 'Ridgeline'.

LAI and fresh weight were significantly greater in the spring experiment than in the fall, but dry weight did not differ between experiments. As a result, DMC was significantly higher in the fall $\left(113 \mathrm{~g} \cdot \mathrm{kg}^{-1}\right)$ than in the spring $\left(43 \mathrm{~g} \cdot \mathrm{kg}^{-1}\right)$. This agrees with the findings of Koudela and Petrikova (2008), who reported that there is a negative correlation between DMC and the weight of lettuce. They found that fresh weight was significantly higher for summer lettuce than for autumn lettuce, whereas DMC was

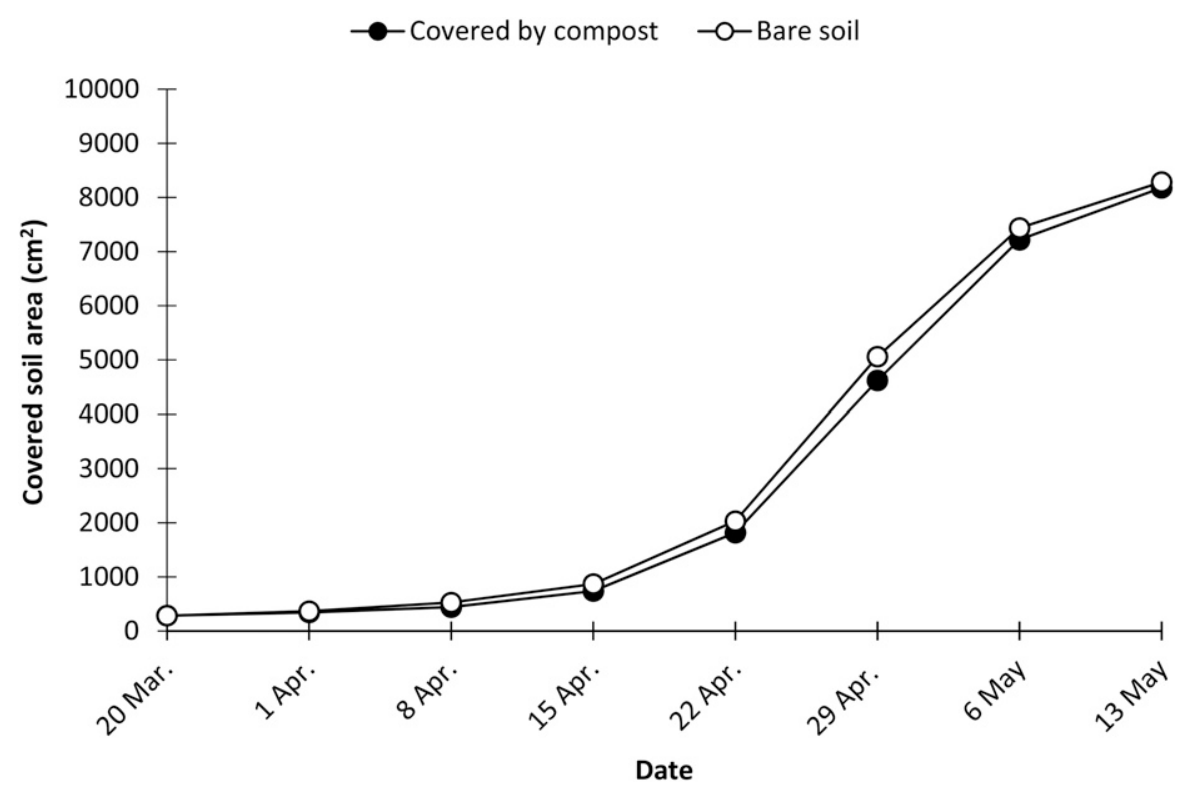

Fig. 4. Change in canopy size, measured as covered soil area, over time for romaine lettuce in soil mulched with multisource compost or left bare. Lettuce was grown in the high tunnel in Spring 2017; data are averages across 16 replications. Means of treatment least squares were not significantly different; $1 \mathrm{~cm}^{2}=0.1550$ inch $^{2}$.

Table 1. The effects of mulch on leaf area index (LAI), fresh weight, and dry matter content (DMC) of romaine lettuce grown in the high tunnel in two seasons.

\begin{tabular}{llccc}
\hline Season & \multicolumn{1}{c}{ Soil cover } & LAI & Fresh wt $\left(\mathbf{k g} \cdot \mathbf{m}^{-2}\right)^{\mathrm{z}}$ & DMC $\left(\mathrm{g} \cdot \mathrm{kg}^{-\mathbf{1}}\right)^{\mathrm{z}}$ \\
\hline \multirow{2}{*}{ Spring } & Compost mulch & $7.87 \mathrm{a}^{\mathrm{y}}$ & $3.23 \mathrm{a}$ & $42.9 \mathrm{a}$ \\
& Bare soil & $8.03 \mathrm{a}$ & $3.22 \mathrm{a}$ & $43.2 \mathrm{a}$ \\
\multirow{2}{*}{ Fall } & Compost mulch & $1.79 \mathrm{a}$ & $1.12 \mathrm{a}$ & $113.4 \mathrm{a}$ \\
& Bare soil & $1.40 \mathrm{~b}$ & $0.92 \mathrm{~b}$ & $112.6 \mathrm{a}$ \\
\hline
\end{tabular}

${ }^{\mathrm{z}} \mathrm{l} \mathrm{kg} \cdot \mathrm{m}^{-2}=0.2048 \mathrm{lb} / \mathrm{ft}^{2}, \mathrm{l} \mathrm{g} \cdot \mathrm{kg}^{-1}=0.0160 \mathrm{oz} / \mathrm{lb}$

${ }^{\mathrm{y}}$ Means separation by Duncan's multiple range at $P<0.05$ for means in the same column within a season.

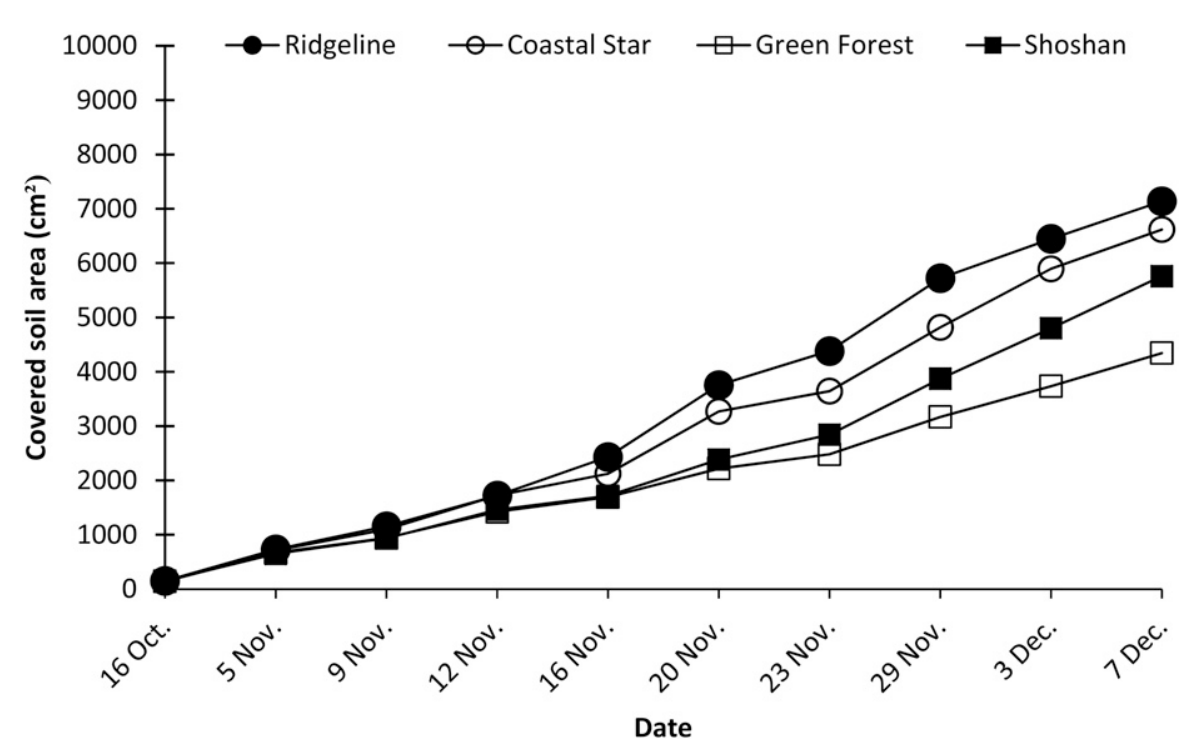

Fig. 5. Change in canopy size, measured as covered soil area, over time for four romaine lettuce cultivars grown in the high tunnel in Fall 2016. Data are averaged across eight replications. Means of cultivar least squares were significantly different $(P<0.01) ; 1 \mathrm{~cm}^{2}=0.1550$ inch $^{2}$. 


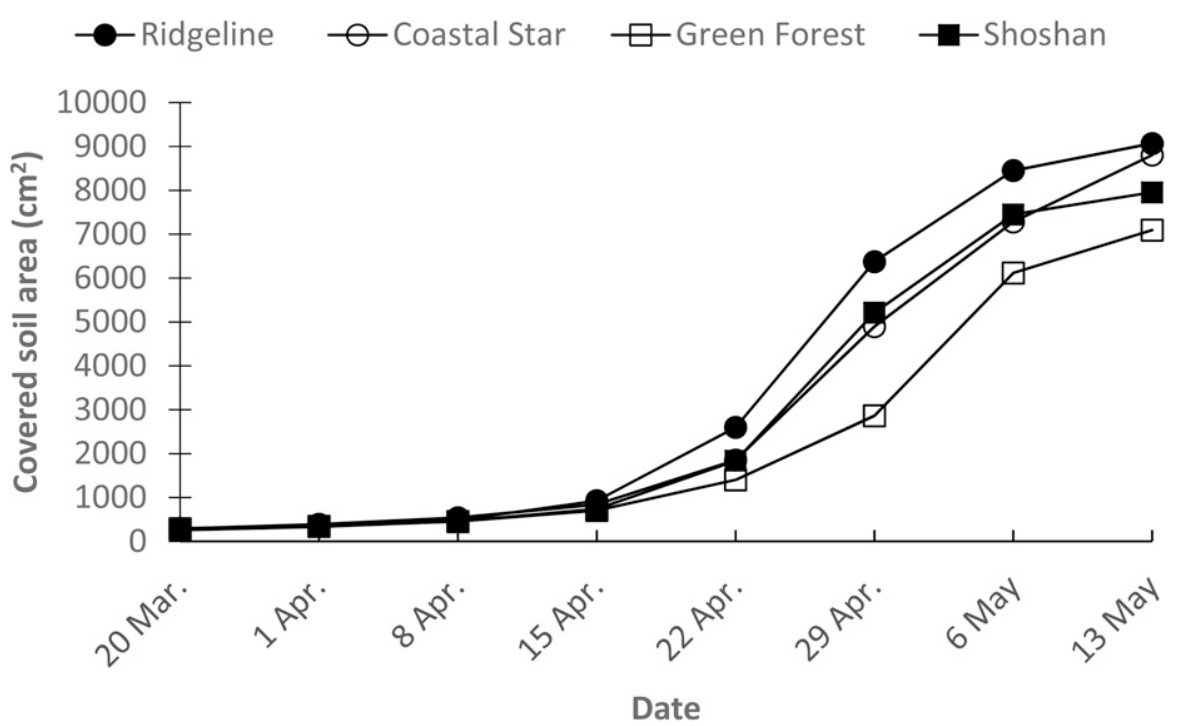

Fig. 6. Change in canopy size, measured as covered soil area, over time for four romaine lettuce cultivars grown in the high tunnel in Spring 2017. Data are averaged across eight replications. Means of cultivar least squares were significantly different $(P<0.01) ; 1 \mathrm{~cm}^{2}=0.1550$ inch $^{2}$.

Table 2. Differences in leaf area index (LAI), fresh weight, and dry weight between lettuce cultivars grown in the high tunnel in two seasons. Values are means of four replications.

\begin{tabular}{|c|c|c|c|c|}
\hline \multirow[b]{2}{*}{ Season } & \multirow[b]{2}{*}{ Cultivar } & \multirow[b]{2}{*}{ LAI } & Fresh wt & Dry wt \\
\hline & & & \multicolumn{2}{|c|}{$\left(\mathrm{kg} \cdot \mathrm{m}^{-2}\right)^{\mathrm{z}}$} \\
\hline \multirow[t]{4}{*}{ Spring } & Ridgeline & $9.09 \mathrm{a}^{\mathrm{y}}$ & $3.69 \mathrm{a}$ & $0.149 \mathrm{a}$ \\
\hline & Coastal Star & $8.35 \mathrm{~b}$ & $3.29 \mathrm{~b}$ & $0.138 \mathrm{c}$ \\
\hline & Green Forest & $5.95 \mathrm{c}$ & $2.83 \mathrm{~d}$ & $0.119 \mathrm{~d}$ \\
\hline & Shoshan & $8.43 \mathrm{~b}$ & $3.08 \mathrm{c}$ & $0.143 \mathrm{~b}$ \\
\hline \multirow[t]{4}{*}{ Fall } & Ridgeline & $1.98 \mathrm{a}$ & $1.26 \mathrm{a}$ & $0.15 \mathrm{a}$ \\
\hline & Coastal Star & $1.68 \mathrm{~b}$ & $1.07 \mathrm{~b}$ & $0.13 \mathrm{~b}$ \\
\hline & Green Forest & $1.06 \mathrm{c}$ & $0.73 \mathrm{c}$ & $0.09 \mathrm{~d}$ \\
\hline & Shoshan & $1.67 \mathrm{~b}$ & $1.02 \mathrm{~b}$ & $0.12 \mathrm{c}$ \\
\hline
\end{tabular}

${ }^{\mathrm{z}} 1 \mathrm{~kg} \cdot \mathrm{m}^{-2}=0.2048 \mathrm{lb} / \mathrm{ft}^{2}$.

'Means separation by Duncan's multiple range at $P<0.05$ for means in the same column within a season.

significantly higher for autumn lettuce than for summer lettuce.

All four cultivars were developed for production of full-size heads. 'Ridgeline' and 'Green Forest' require $56 \mathrm{~d}$ to mature under optimal conditions, 'Coastal Star' requires $57 \mathrm{~d}$, and 'Shushan' requires $65 \mathrm{~d}$. Cooler day and night air temperatures, below $40^{\circ} \mathrm{F}$, will slow the growth of lettuce plants and increase the time to maturity by at least 7-10 d (Orzolek, 2012). 'Shushan' is from an arid area. 'Ridgeline' and 'Coastal Star' were grown from organic seed, whereas 'Shoshan' and 'Green Forest' were conventional seed. In an open field trial during the summer in Indiana, 'Green Forest' heads were twice as large as heads of 'Coastal Star' (Maynard, 2013). By contrast, 'Ridgeline' had the largest heads in a winter trial in Hawaii, outyielding both 'Coastal Star' and 'Green Forest' (Uyeda et al., 2014). This suggests that 'Green Forest' is better suited to summer production.

Economic analysis. The compost used in this study was purchased in bulk at a cost of $\$ 22.50 /$ yard $^{3}$. We used 7.5 yard $^{3}$ to cover $115.2 \mathrm{~m}^{2}$, resulting in a cost of $\$ 1.46 / \mathrm{m}^{2}$ for the mulch. Spreading the mulch required eight person-hours at a cost of $\$ 12 / \mathrm{h}$ for a labor cost of $\$ 0.38 / \mathrm{m}^{2}$. No weeding was required in the mulched plots, resulting in total variable costs of $\$ 1.84 / \mathrm{m}^{2}$. Labor for weeding was the only variable cost in the bare ground plots; eight person-hours of weeding were required in the fall experiment and 12 person-hours in the spring experiment. Total variable costs were $\$ 0.38 / \mathrm{m}^{2}$ in the fall and $\$ 0.57 / \mathrm{m}^{2}$ in the spring. Using compost mulch for a single lettuce crop does not reduce labor costs for lettuce production because labor for weeding is replaced with labor for spreading mulch. If a single application of mulch is used for two lettuce crops, labor costs could be reduced by $50 \%$, but reduction in labor would not cover the cost of the mulch itself. However, if farmers are applying compost in high tunnels as a soil amendment, the costs for labor and material are similar whether the compost incorporated before planting fall lettuce, or left on the surface as a mulch.

A retail value of $\$ 2 / \mathrm{lb}$ was used to calculate income from the lettuce crop. At this price, a yield increase of $1.5 \mathrm{lb} / \mathrm{m}^{2}$ would be required to cover the expense of the compost. Mulched plots of 'Ridgeline' in the fall experiment yielded enough additional lettuce to cover the cost of the compost.

\section{Conclusions}

The objective of this study was to determine how using compost as an organic mulch for weed suppression affected yields of romaine lettuce cultivars grown in the late fall and early spring when below-optimal soil temperatures could limit lettuce growth. Organic mulch has been shown to reduce soil temperatures, and we hypothesized that it would reduce lettuce yields in the late fall and early spring. However, the use of compost as an organic mulch significantly increased lettuce yields when extending the harvest season into late fall and did not negatively affect yields in early spring. Soil in the mulched plots was significantly warmer than soil in the bare ground plots in the fall study, suggesting that mulch acted as an insulating layer slowing the decrease of soil temperature as air temperatures decreased. In the spring, mulch significantly reduced diurnal fluctuation in soil temperatures but did not affect the mean temperature. The mulch effectively suppressed weeds in both experiments, eliminating the need for hand weeding in the mulched plots. Unmulched plots required hand weeding twice in the fall and three times in the spring. Using compost mulch increased the cost of production by $\$ 1.46 / \mathrm{m}^{2}$ in the fall and by $\$ 1.29 / \mathrm{m}^{2}$ in the spring. In this study, labor requirements for spreading compost mulch were similar 
to those for weeding the bare soil plots; increased costs reflect the cost of the compost. In the fall experiment, mulching increased yields of 'Ridgeline' by $0.33 \mathrm{~kg} \cdot \mathrm{m}^{-2}$. At a retail value of $\$ 2 / \mathrm{lb}$, the increased yields for 'Ridgeline' would just cover the increased cost of production. Even if the use of compost mulch to control weeds and warm the soil for fall lettuce does not increase profits, organic mulch would build soil organic matter and improve soil structure. The use of compost as a mulch in either fall or spring does not decrease yields or delay maturity. Farmers who apply compost annually in their high tunnels to enhance soil fertility should consider leaving the compost on the surface as a mulch for fall and spring lettuce production, and then incorporating the compost before planting summer crops.

\section{Literature cited}

Bonanomi, G., R. D'Ascoli, R. Scotti, S.A. Gaglione, M. Gonzalez Caceres, S. Sultana, R. Scelza, M.A. Rao, and A. Zoina. 2014. Soil quality recovery and crop yield enhancement by combined application of compost and wood to vegetables grown under plastic tunnels. Agr. Ecosyst. Environ. 192:1-7.

Bruce, A.B., J.R. Farmer, E.T. Maynard, and J.C.D. Valliant. 2017. Assessing the impact of the EQIP high tunnel initiative. J. Agr. Food Syst. Community Dev. 7: 159-180.

Bumgarner, N.R., M.A. Bennett, P.P. Ling, R.W. Mullen, and M.D. Kleinhenz. 2011. Canopy cover and root-zone heating effects on fall and spring grown leaf lettuce yield in Ohio. HortTechnology 21:737-744.

Bumgarner, N.R., W.S. Miller, and M.D. Kleinhenz. 2012. Digital image analysis to supplement direct measures of lettuce biomass. HortTechnology 22:547-555.

Cowan, J.S., C.A. Miles, P.K. Andrews, and D.A. Inglis. 2014. Biodegradable mulch performed comparably to polyethylene in high tunnel tomato (Solanum lycopersicum L.) production. J. Sci. Food Agr. 94:1854-1864.

Deguchi, S., H. Kawamoto, O. Tanaka, A. Fushimi, and S. Uozumi. 2009. Compost application increases the soil temperature on bare Andosol in a cool climate region. J. Soil Sci. Plant Nutr. 55:778-782.

Eaton, A.T. 2017. Managing voles in vegetable crops and high tunnels. Proc. New England Veg. Fruit Conf., 12-14 Dec. 2017, Manchester, NH. p. 67-69.
Goldberger, J., R. Jones, C. Miles, R.W. Wallace, and D.A. Inglis. 2015. Barriers and bridges to the adoption of biodegradable plastic mulches for U.S. specialty crop production. Renew. Agr. Food Syst. 30:143-153.

Hernández, T., C. Chocano, J.L. Moreno, and C. García. 2016. Use of compost as an alternative to conventional inorganic fertilizers in intensive lettuce (Lactuca sativa L.) crops-Effects on soil and plant. Soil Tillage Res. 160:14-22.

Hunter, B.L. 2010. Enhancing out of season production of tomatoes and lettuce using high tunnels. Utah State Univ., Logan, Master's Thesis.

Kim, M.J., M. Youyoun, D.A. Kopsell, S. Park, J.C. Tou, and N. Waterland. 2016. Nutritional value of crisphead 'Iceberg' and romaine lettuces (Lactuca sativa L.). J. Agr. Sci. 8:1-10.

Knewtson, S.J.B., E.E. Cary, and M.B. Kirkham. 2010. Management practices of growers using high tunnels in the central Great Plains of the United States. HortTechnology 20:639-645.

Knewtson, S.J.B., M.B. Kirkham, R.R. Janke, L.W. Murray, and E.E. Carey. 2012. Soil quality after eight years under high tunnels. HortScience 47:1630-1633.

Koudela, M. and K. Petrikova. 2008. Nutrients content and yield in selected cultivars of leaf lettuce (Lactuca sativa L. var. crispa). Hort. Sci. (Prague) 35:99-106.

Kosterna, E. 2014. Organic mulches in the vegetable cultivation: A review. Ecol. Chem. Eng. A 21:481-492.

Lamont, W.J. 2009. Overview of the use of high tunnels worldwide. HortTechnology 19:25-29.

Lamont, W.J., M.D. Orzolek, E.J. Holcomb, K. Demchak, E. Burkhart, L. White, and B. Dye. 2003. Production system for horticultural crops grown in the Penn State high tunnel. HortTechnology 13:358-362.

Martinez, S., M. Hand, M. Da Pra, S. Pollack, K. Ralston, T. Smith, S. Vogel, S. Clark, L. Lohr, S. Low, and C. Newman. 2010. Local food systems: Concepts, impacts, and issues. U.S. Dept. Agr. Econ. Res. Serv. ERR 97.

Maynard, E.T. 2013. Lettuce cultivar observation trial. Midwest vegetable trial report for 2013. 18 Jan. 2018. <https:// ag.purdue.edu/hla/fruitveg/MidWest\% 20Trial\%20Reports/2013/04-02_ Maynard_Lettuce.pdf $>$.

Munn, D.A. 1992. Comparisons of shredded newspaper and wheat straw as crop mulches. HortTechnology 2:361-366.
Nair, A. and B.J. Havlovic. 2012. Mulch and row cover affect lettuce production in high tunnels. Iowa State Res. Farm Prog. Rpt. Paper 1864. 20 Jan. 2017. <http:// lib.dr.iastate.edu/farms_reports/1864>.

Orzolek, M.D. 2012. Lettuce production systems in high tunnels. 30 June 2018. <http://www.hort.cornell.edu/expo/ proceedings/2012/Winter\%20Greens $>$.

Patrignani, A. and T.E. Ochsner. 2015. Canopeo: A powerful new tool for measuring fractional green canopy cover. Agron. J. 107:2312-2320.

Rader, H.B. and M.G. Karlsson. 2006. Northern field production of leaf and romaine lettuce using a high tunnel. HortTechnology 16:649-654.

Ryder, E.J. 2002. The new salad crop revolution, p. 408-412. In: J. Janick and A. Whipkey (eds.). Trends in new crops and new uses. ASHS Press, Alexandria, VA.

Salomez, J. and G. Hofman. 2007. A soil temperature/short-wave radiation growth model for butter head lettuce under protected cultivation in Flanders. J. Plant Nutr. 30:397-410.

Sánchez, E., W.J. Lamont, and M.D. Orzolek. 2008. Newspaper mulches for suppressing weeds for organic high-tunnel cucumber production. HortTechnology 18:154-157.

U.S. Department of Agriculture. 2014. 2012 Census of agriculture. U.S. Dept. Agr., Natl. Agr. Stat. Serv., Washington, DC.

U.S. Department of Agriculture. 2018. Vegetables 2017 summary. U.S. Dept. Agr., Natl. Agr. Stat. Serv., Washington, DC.

Uyeda, J., J. Sugano, S. Fukuda, T. Radovich, A. Pant, and H. Valenzuela. 2014. Evaluation of romaine lettuce varieties for commercial production from 2011-2014. CTAHR Coop. Ext. Serv. Food Safety Technol. Rpt. VC-3.

Van Der Boon, J., J.W. Steenhuizen, and E.G. Steingrover. 1990. Growth and nitrate concentration of lettuce as affected by total nitrogen and chloride concentration, NH4/N03 ratio and temperature of the recirculating nutrient solution. J. Hort. Sci. 65:309-321.

Wallace, R.W., A.L. Wszelaki, C.A. Miles, J.S. Cowan, J. Martin, J. Roozen, B. Gundersen, and D.A. Inglis. 2012. Lettuce yield and quality when grown in high tunnel and open-field production systems under three diverse climates. HortTechnology 22:659-668.

Wortman, S.E., I. Kadoma, and M.D. Crandall. 2016. Biodegradable plastic and fabric mulch performance in field and high tunnel. HortTechnology 26:148-155. 